IZA DP No. 7753

Nuns and the Effects of Catholic Schools:

Evidence from Vatican II

Rania Gihleb

Osea Giuntella

November 2013 


\title{
Nuns and the Effects of Catholic Schools: Evidence from Vatican II
}

\author{
Rania Gihleb \\ Boston University \\ Osea Giuntella \\ University of Oxford \\ and IZA \\ Discussion Paper No. 7753 \\ November 2013 \\ IZA \\ P.O. Box 7240 \\ 53072 Bonn \\ Germany \\ Phone: +49-228-3894-0 \\ Fax: +49-228-3894-180 \\ E-mail: iza@iza.org
}

\begin{abstract}
Any opinions expressed here are those of the author(s) and not those of IZA. Research published in this series may include views on policy, but the institute itself takes no institutional policy positions. The IZA research network is committed to the IZA Guiding Principles of Research Integrity.

The Institute for the Study of Labor (IZA) in Bonn is a local and virtual international research center and a place of communication between science, politics and business. IZA is an independent nonprofit organization supported by Deutsche Post Foundation. The center is associated with the University of Bonn and offers a stimulating research environment through its international network, workshops and conferences, data service, project support, research visits and doctoral program. IZA engages in (i) original and internationally competitive research in all fields of labor economics, (ii) development of policy concepts, and (iii) dissemination of research results and concepts to the interested public.
\end{abstract}

IZA Discussion Papers often represent preliminary work and are circulated to encourage discussion. Citation of such a paper should account for its provisional character. A revised version may be available directly from the author. 
IZA Discussion Paper No. 7753

November 2013

\section{ABSTRACT \\ Nuns and the Effects of Catholic Schools: Evidence from Vatican II}

This paper examines the causal effects of Catholic schooling on educational attainment. Using a novel instrumental-variable approach that exploits an exogenous shock to the Catholic school system, we show that the positive correlation between Catholic schooling and student outcomes is explained by selection bias. Spearheaded by the universal call to holiness and the opening to lay leadership, the reforms that occurred at the Second Vatican Council (Vatican II) in the early 1960s produced a dramatic exogenous change in the cost/benefit ratio of religious life in the Catholic Church. The decline in vocations that followed contributed to a significant increase in costs and, in many cases, to the closure of Catholic schools. We document that this decline was heterogeneous across US dioceses, and that it was more marked in those dioceses governed by a liberal bishop. Merging diocesan data drawn from the Official Catholic Directory (1960-1980) and the US Census, we show that that the variation in the supply of female religious teachers across US dioceses is strongly related to Catholic schooling. Using the abrupt decline in female vocations as an instrument for Catholic schooling, we find no evidence of positive effects on student outcomes.

JEL Classification: $\quad$ I20, J24, N3

Keywords: Catholic schools, instrumental variable, selection

Corresponding author:

Osea Giuntella

Blavatnik School of Government

University of Oxford

12 Merton Street

Oxford, Oxfordshire

United Kingdom

E-mail: osea.giuntella@bsg.ox.ac.uk

\footnotetext{
* We are thankful to Randall Ellis, Larry Kotlikoff, Kevin Lang, Robert Margo, Claudia Olivetti, and Daniele Paserman for their comments and advice. Hannah Ye and Xi Chen provided excellent research assistance. We benefited from discussion with Eli Berman, Fabrizio Mazzonna, Catia Nicodemo, and Lawrence lannaccone, and thank seminar participants at the Tinbergen Institute, Boston University, and the 2012 Association for the Study of Religion, Economics, and Culture Conference. Finally, we would like to thank Sr. Anna Caiazza, Sr. Dale McDonald, Sr. Christina Wegendt, and the Boston College O'Neill Library for helping us in the data collection process. Any errors are our own.
} 


\section{Introduction}

Several empirical studies attempted to assess whether private schools provide better education than public schools. This question is crucial in the debate on public versus private schools and, more generally, on the effectiveness of school choice. Advocates of school competition and vouchers often rely on research evidence suggesting positive effects of private schooling on educational outcomes. Most researchers have focused their attention on the role of Catholic schools, which account for the largest share of private schools, analyzing their performance and effectiveness. There is a substantial consensus on the positive correlations between Catholic school attendance and educational outcomes. However, a causal interpretation of these findings has been severely limited by the spurious correlation between Catholic school attendance and other unobserved characteristics that may affect educational outcomes. Most of the previous studies attempted to estimate the effects of Catholic schooling on student outcomes using different instrumental strategies (e.g., religious affiliation, distance from the Catholic schools, density of Catholic population), and found evidence of positive effects of Catholic schooling on high school graduation and college attendance rates. More recently, Altonji et al. (2005) cast doubt on the holding of the exclusion restrictions for the proposed instruments. The authors of that study used a different method based on the idea that selection on the observed characteristics provides a measure of the potential selection on the unobservables. Following this approach, they found positive effects of Catholic schooling on high school graduation and college attendance, but their results suggest smaller effects than previous studies and no evidence of significant effects on test scores. Adopting similar techniques, Elder and Jepsen (2013) find evidence of negative effects of Catholic primary schooling on math scores. Cohen-Zada and Elder (2009) proposed an alternative instrument based on the historical Catholic concentration in a county. They argued that historical Catholic shares are much more likely to be exogenous to student outcomes than previous instruments used in the literature. Their results are similar to those of Altonji et al. (2005). Yet, a potential omitted variable bias may still exist if historical shares are correlated 
with other unobservable characteristics of the local area, such as private competition or local population density.

We contribute to the literature using a new strategy. With the universal call to holiness and the opening to lay leadership, the Second Vatican Council (Vatican II) in the early 1960s inadvertently produced a dramatic change in the cost/benefit ratio of religious life and drained Catholic schools of critical human capital. Between 1966 and 1980, the number of Catholic sisters (nuns) was reduced by more than 30\%. This unexpected collapse was followed by a parallel decline in the number of Catholic schools in operation. Following the decline in the number of Catholic sisters, the share of religious teachers in Catholic schools fell by more than 50\%. Because religious teachers were paid, on average, one-third the amount that lay teachers were paid, the sudden and rapid shift in personnel imposed severe financial constraints on Catholic schools and forced many schools to close. The closure of Catholic schools was mostly caused by supply effects and was not driven by changes in the demand for Catholic schooling (Caruso, 2012). The decline in the supply of Catholic sisters was also more marked in dioceses that were more exposed to the reforms that occurred at the Second Vatican Council (Stark and Finke, 2000). We argue that the heterogeneity in the decline in vocations is partially explained by the unpredictable reactions of local bishops to the "religious earthquake" occurring in Rome. We use the sudden shock to the supply of Catholic sisters and its heterogeneous impact across US dioceses as an exogenous instrument for Catholic schooling. This approach allows us to control for both local area fixed effects, which account for time-invariant characteristics, and cohort fixed effects, which capture any systematic difference in school outcomes across cohorts. At the same time, we control for a set of local-area time-varying characteristics. In addition, the focus of extant literature has been on the effectiveness of Catholic high schools. However, little is known about the effectiveness of Catholic primary schools. This paper focuses on the effects of Catholic schooling on grade repetition of students aged 7-15 years of age, and contributes to a recent set of studies on the effectiveness of Catholic primary schools (Elder and Jepsen, 2013; Reardon et al., 2009; 
Lubienski et al., 2009; Carbonaro, 2006). To conduct this analysis, we assembled a unique dataset based on the diocesan records of Catholic sisters, priests, and schools from 1960 to 1980, which was drawn from the Official Catholic Directory (OCD). We use these data to document the trends in the human assets of the Catholic Church and Catholic schools before and after the Second Vatican Council. Using voting records from Vatican II collected by Wilde (2007) to classify the bishops into progressive and conservative categories, we provide evidence that the change in the number of sisters per Catholic diocese was more pronounced in dioceses governed by liberal bishops. We then merge the diocesan data with US Census information for different cohorts of students who were in school between 1960 and 1980. The US Census data contain individual information on parochial school attendance for individuals enrolled in school at the time of the census. ${ }^{1}$ While these data do not contain information on test scores, we can use the information on educational attainment to analyze the effects of Catholic schooling on grade repetition. Our results show that the rapid decline in vocations was associated with a significant decline in Catholic schooling despite an increase in the Catholic population resulting from new immigrant inflows. In particular, a one standard deviation decrease in the number of Catholic sisters in a metropolitan statistical area (MSA) is associated with a $14 \%$ reduction in a student's likelihood of attending a Catholic school. We provide evidence that our instrument is more likely to be exogenous rather than the alternative instrumental variable strategies previously used in the literature. Turning to the analysis of the effects of Catholic schooling on educational performance, ordinary least squares (OLS) estimates confirm a positive relationship between attending a Catholic school and school outcomes. However, using the number of Catholic sisters in a given cohort-MSA as an instrument for Catholic schooling, we do not find evidence of significant effects on grade repetition and reject the OLS estimates; if anything, we find evidence of negative effects.

\footnotetext{
${ }^{1}$ The U.S. Census does not identify the religious denomination of the school, only whether the school was a "parochial" or "church-related" school. However, the vast majority of private schools over the period considered in the paper were Catholic schools (Kim, 2011). Of course, this is even more pronounced when restricting the analysis to parochial schools. Therefore, we will use parochial and Catholic schools interchangeably.
} 
These results suggest that the OLS estimates are entirely driven by a positive selection bias. To verify the plausibility of our results, we also use the techniques of Altonji et al. (2005) and show that even a modest degree of selection on unobservables is sufficient to eliminate and reverse the sign of Catholic schooling. When examining different measures of educational attainment (high school dropout rates, high school graduation rates, and the rate of college attendance) using reduced-form relationships, we find no evidence of positive effects. Finally, we discuss whether the sudden shock to the number of religious teachers affects the validity of our identification strategy by changing the average quality of surviving Catholic schools. Focusing on children attending Catholic schools, we provide evidence that the share of religious teachers was negatively associated with grade repetition. If the prior assumption is that the higher quality of Catholic sisters had a significant and positive impact on student school outcomes, we should expect our reduced-form coefficient to be upwardbiased. Because we find a null or negative effect, we interpret our two stage least squares (2SLS) estimate as plausibly identifying an upper bound on the Catholic school effects on student outcomes.

The paper is organized as follows. Section 2 provides a brief description of the Second Vatican Council and its causes and consequences. In Section 3, we describe the identification strategy and the data. The results are presented and discussed in Section 4. Section 5 concludes.

\section{The Second Vatican Council and the Decline in Vo- cations}

Less than three months after his election, Pope John XXIII announced his decision to convene a new Council in Rome to "open the windows of the Church and let some fresh air in". Given that the Conclave elected Angelo Roncalli, nearly eighty years old, in the context of a transitional pontificate, no one expected this to happen. The surprising 
decision of calling a new Vatican Council was undertaken by the pope alone, exercising his papal primacy. Alberigo (2006), one of the most qualified historians to comment on Vatican II, starts his brief history of the Second Vatican Council by remarking how the popes announcement "was unexpected and surprising for most sectors of the Church, which were dominated by the climate of the Cold War and satisfied with a Catholicism unyielding its certainties". ${ }^{2}$ The purpose of the Council was to "recognize the signs of times" and to discuss and update the major features of Catholic doctrine and practice. For the purposes of this paper, it is important to note that most scholars emphasize the exogenoeity of the popes announcement. Not only was the Curia caught by surprise, but even liberal scholars and Council reformers, such as Alberigo, did not expect the pope to convene all of the Bishops in Rome to renew and update the Church's beliefs, liturgies and practices (Stark and Finke, 2000; Berman et al., 2012). These changes had important practical and theological consequences on the life of the entire Catholic Church, starting with the life of religious men and women. Stark and Finke (2000) explain in depth how three Vatican II documents (Lumen Gentium, Gaudium et Spes and the Perfectae Caritatis) involved important changes to religious life. In particular, by establishing the universal call to holiness, the Lumen Gentium helped overcome the notion of the superior holiness of the religious state and gave new importance to the role of lay people in the Church. Overall, the Second Vatican Council emphasized the need of the Church to recognize "what changes with the passing of time" and to open itself to the modern world. Stark and Finke (2000) and Berman et al. (2012) note how these changes unintentionally affected the marginal benefits of a religious life by eliminating the superiority of religious status without substantially reducing the costs of a religious life, such as the vows of celibacy and poverty. The changes in the cost-benefit ratio of a religious life were marginally higher for women. Indeed, the Vatican II did not bring any progress to the ordination of women in the Church and de facto equiparated Catholic sisters to lay women in their path to "holiness". The loss of this special status contributed

\footnotetext{
${ }^{2}$ As reported in Alberigo (2006), the pope himself later acknowledged in the Journal of Soul that the Vatican Council was entirely the popes initiative.
} 
to the large decline in the late 1960s and early 1970s in the number of religious women. Scholars agree that these shocks in the life of the Catholic Church were the primary causes of the unexpected decline in vocations and the rise in defections. However, the debate on the mechanism underlying these patterns persists, with liberals arguing that priests and nuns left the Church because they had been hoping for more extensive reforms and conservatives blaming the Churchs excessive modernization and the universal call to holiness for the decline in vocations (Ebaugh, 1993; Stark and Finke, 2000). Like Berman et al. (2012), who use the natural experiment provided by the Second Vatican Council and the decline in female vocations to explain fertility patterns in Europe, we do not focus directly on the causes of the decline. ${ }^{3}$ We are simply interested in establishing the exogeneity of the shock to the supply of Catholic sisters and its validity as an instrument for studying the effects of Catholic schooling. In particular, it is important to establish that this shock was exogenous and not related to individual unobservable characteristics that may affect both Catholic schooling and student outcomes. The obvious concern when using a historical event as a natural experiment is that there may have been several other factors affecting Vatican II that may explain the trends in vocations and be endogenous to the outcome of interest. One could think that female religious vocations decreased because of the expanded opportunities for women. Stark and Finke (2000) argue that the timing of the collapse in vocations suggests that other factors, such as trends in income and female labor force participation, played only minor roles in explaining the abrupt reduction in the number of Catholic sisters. After World War II, female labor force participation and income grew slowly and steadily. On the contrary, as shown in Figure 1, there was a steady growth in the number of nuns until the mid 1960s, followed by a rapid decline thereafter. We further discuss the validity of our identification strategy in the next section.

\footnotetext{
${ }^{3}$ The researchers use a panel on church attendance and clergy employment for the years 1960-2000 and show evidence that the interaction of the service provision and religiosity largely explains the declining fertility observed in Southern Europe. In particular, they show that their results are consistent with a model in which social service provided by the Church affects fertility by lowering the cost of raising children.
} 


\section{Data and Empirical Specification}

We use data from three main sources: the US diocesan records contained in the Official Catholic Directory; the records of votes expressed at the Second Vatican Council, collected by Wilde (2007); and individual data drawn from the US Census (1970 and 1980) containing information on parochial school attendance and educational attainment. The Official Catholic Directory (OCD) was first published in 1817 by P.J. Kennedy \& Sons and contains detailed annual statistics on American dioceses, including the number of priests and nuns serving the dioceses, and the number of seminarians, Catholic schools, and religious and lay teachers. We collected data for the years 1961 to 1980 for each US diocese. ${ }^{4}$ To be able to conduct a consistent analysis over time and across US dioceses, we constructed a balanced panel of dioceses for which we have information available for every year since 1961. In cases where new dioceses were created, we aggregated the information to reconstruct the original set of dioceses. In the few cases in which a new diocese was created by merging the territories of two or more dioceses, we attributed the numbers of the new diocese to the major contributing diocese. ${ }^{5}$ After performing these adjustments, we were left with a panel of 122 dioceses for which we had consistent information for the period between 1961-1980. ${ }^{6}$

\subsection{Catholic Sisters and Parochial Schools Before and After the Second Vatican Council}

Figure 1 shows the pattern of vocations and changes in the staff composition in Catholic schools over time. As previously noted, in the years preceding the Second Vatican Council, there was substantial and steady growth in the number of nuns and more moderate growth in the number of Catholic priests. The increase in the number of nuns was accompanied by

\footnotetext{
${ }^{4}$ Figure 5 shows an extract of the Diocesan data in the Official Catholic Directory for 1965.

${ }^{5}$ When using alternative criteria such to excludeing these dioceses from our analysis, our results were not substantially changed.

${ }^{6}$ We excluded from the analysis the Vicariate Apostolic of Alaska, the Belmont Abbey, the Byzantine Rite and the Pittsburgh (Greek Rite) diocese.
} 
an expansion of the Catholic school system in the US, which was reflected in the growth of sisters and lay teachers. However, in the years immediately following the Second Vatican Council, we observe a sharp decline in the number of nuns. This decline is only partially compensated for by the increase in the number of lay teachers in Catholic schools. The number of Catholic sisters reached a peak of approximately 180,000 in 1966 and then fall dramatically to approximately 125,000 in $1980(-30 \%) .{ }^{7}$ During the same period, the number of lay teachers increased significantly $(+56 \%)$. However, this increase could not compensate for the decline in the number of sisters who were teachers. ${ }^{8}$ Catholic sisters accounted for $60 \%$ of the total number of teachers in 1960 but for less than $25 \%$ in 1980 . Because religious teachers were, on average, paid one third the amount that lay teachers were paid, the dramatic collapse of female vocations had an immediate impact on tuitions and the ability of parishes to keep their schools open by replacing former religious teachers with lay teachers. ${ }^{9}$ Figure 2 illustrates how the trends in Catholic schools across US dioceses closely resemble the trends in female religious vocations. Between 1965 and 1980, the number of parochial high schools declined by approximately $40 \%$ and parochial elementary schools by

${ }^{7}$ Ebaugh (1993) remarks how the sharp decline in the number of Catholic sisters between 1966 and 1986 was due to both a decrease in the rate of entry and an increase in defections. The shortage of new vocations and the fact that the majority of those defecting were under the age of 40 dramatically affected the age structure within the religious orders. Within a few years, the percentage of sisters over 65 years of age doubled from $17 \%$ in 1966 to $38 \%$ in 1982 (Neal, 1984).

${ }^{8}$ Interestingly, the absolute number of priests remained relatively stable over the evaluated period of time. However, after normalizing by the size of the Catholic population, the decline followed a similar, although less marked, pattern. This is consistent with the idea suggested by Stark and Finke (2000) that the changes occurring at the Second Vatican Council were particularly devastating for women who, "unlike males, had never been granted ordination, and now their holiness was reduced to that of all other lay Catholics".

${ }^{9}$ Differences in the extent of the vow of poverty and the congregational needs reflected different salaries across congregations and schools. Unfortunately, we did not find more precise data regarding religious women's salaries. However, Finke and Stark (2005) emphasize that religious women's salaries were not only lower than those of public school teachers but also lower than those of religious brothers who were teachers. We found more information regarding the salaries paid to lay teachers (see Hesburgh et al. (1966), which were also lower than those paid to public school teacher, but still approximately three times higher, on average, than salaries paid to Catholic sisters. Koob and Shaw (1970) report than in the late 1960s, lay teachers" salaries in many dioceses were set at $90-95 \%$ of public school salaries. The increased need for lay teachers forced Catholic schools to provide more competitive salaries to attract trained teachers. The gap between religious and lay teacher salaries shrank over the most recent years, likely due to the increasing financial difficulties facing religious congregations (Fialka, 2003). In 2009, however, a religious teacher was paid, on average $(30,806 \$)$, approximately $4,000 \$$ less than a lay teacher $(34,656 \$)$ in a Catholic school. Additionally, less than $30 \%$ of the schools applied the same rate to the two categories of teachers. 
$35 \%$. It is worth noting that the decline in the number of Catholic schools occurred in a context of the "voracious demand of families for Catholic schools", as noted by Caruso (2012). The closure of Catholic schools was largely the result of supply effects. Without nuns to staff schools, Catholic schools were forced to hire lay teachers and pay competitive salaries to meet demand. The increase in the share of lay teachers became financially unbearable, forcing schools to increase their tuition fees or to close (Caruso, 2012; Dolan, 1992; Bryk et al., 1993).

\subsection{Heterogeneity Across US Dioceses}

The decline in female religious vocations was heterogeneous across the different dioceses. Scholars speculated that the variation in the decline across US dioceses can be partially explained by variation in the receptiveness of the dioceses to Vatican II reforms. With the help of a group of experts, Stark and Finke (2000) classified dioceses to identify those that were most traditional and progressive. They showed that liberal dioceses faced a sharper decline in religious vocations in the aftermath of Vatican II. We take a different approach and use the voting records of Bishops at Vatican II to classify progressive and conservative bishops. Wilde (2007) obtained Council votes from the Vatican Secret Archive (Archivio Segreto Vaticano) and entered them into an electronic database that is now publicly available on the ARDA website. The voting data contain information on individual bishops, their dioceses and their votes on ten of the most contentious Council reforms. As suggested by Wilde (2007), we use the vote on the document "On the Sources of Revelation" as a measure of the Bishops openness to change. "On the Sources of Revelation" is a particularly conservative document refuting the historical and anthropological contextualization of the Bible and emphasizing the importance of Church "tradition" with respect to the scripturecentered protestant culture. Because most of the bishops who expressed liberal views in the other votes opposed this document, we define a bishop as liberal if he voted against

it. In cases where two or more bishops participating at the Council resided in the same 
diocese, we averaged the votes and considered the dioceses where the votes where tied to be conservative. ${ }^{10}$ Figure 3 and Table 1 provide evidence that the change in the number of sisters per Catholic school was more pronounced in liberal dioceses. In Figure 3, we show how the number of Catholic sisters, sister teachers, parochial elementary schools and high schools follow a similar pattern. However, the decline following Vatican II occurred at a faster rate in liberal dioceses (solid line in the graphs). Table 1 shows that, accounting for persistent differences in the dioceses and time fixed effects, the fall in the number of Catholic sisters per Catholic was $11 \%$ lower in conservative dioceses than in liberal dioceses (see column 1). Column 2 reports a similar pattern when we look at the number of sister teachers. The difference in the rate of decline is more evident when we focus on the most conservative dioceses as classified by Stark and Finke (2000) (see columns 3 and 4). ${ }^{11}$ For these dioceses, the decline was approximately $65 \%$ lower than what we observed for the more liberal dioceses. The evidence presented suggests that the heterogeneity in the decline of vocations was partially explained by the reactions of bishops to the "religious earthquake" occurring in Rome. Moreover, the votes of bishops at the Second Vatican Council and, more generally, their attitudes toward the unexpected reforms were largely unpredictable at the beginning of the Council (Alberigo, 2006; Wilde, 2007). Taken together, this analysis strengthens our belief that the variation in the decline in the number of Catholic sisters was exogenous to unobservable time-varying diocesan characteristics that may have been correlated with both the drop in the number of nuns and student outcomes. Under this identifying assumption, we exploit the sudden shock to the supply of Catholic sisters and its heterogeneous impact across US dioceses as an exogenous instrument for parochial schooling.

\footnotetext{
${ }^{10}$ Alternatively, we considered only the vote of the residential bishop and found no significant differences in the main results.

${ }^{11}$ When comparing the most conservative and most liberal dioceses, we adopted the same categorization used by Stark and Finke (2000), who asked a group of experts to identify the ten most traditional and the ten most liberal dioceses. We consider the following dioceses to be traditional: Lincoln, Arlington, Bridgeport, Scranton, St. Louis, and Camden. We consider the following dioceses to be the most liberal: Saginaw, New Ulm, Albany, Milwaukee, Joliet, San Francisco, Rochester, and Richmond.
} 


\subsection{Identification Strategy}

Figure 4 illustrates the heterogeneity in the decline in the number of Catholic sisters and parochial schools across US states in the aftermath of Vatican II. Our identification follows a difference-in-difference approach, exploiting the variation in the availability of Catholic sisters across US Census Metropolitan Statistical Areas (MSAs) between 1960 and 1980, covering the years preceding and following the Second Vatican Council. We merged the panel of US dioceses with the 1\% US Census Sample of 1970 and the 5\% US Census Sample of $1980 .{ }^{12}$ Following the previous literature (Lankford and Lee, 1995), we assigned to each MSA the diocesan characteristics of the dioceses contained in the MSA. ${ }^{13}$ Averages across dioceses were used whenever an MSA included counties from more than one diocese. As a robustness check, we collected data at the county level for the four largest dioceses (Chicago, Detroit, Los Angeles, and New York) and merged them with the US census data at the county-level. The US Census does not contain information on Catholic schooling but it does contain information on parochial and private schooling attendance. ${ }^{14}$ We focus on the population of children between 7 and 15 years of age, who were the most likely to live with their parents and therefore who were more likely to be represented in the sample. Focusing on this group allows us to use the information on current enrolment in a parochial or public school in the census year. US Census data contain only limited information on children's outcomes. However, grade retention can be computed using information on educational attainment and age. Grade retention has been shown to be significantly correlated with other measures of educational performance (Oreopoulos et al., 2006; Shepard and Smith, 1989). As in Oreopoulos et al. (2006), we define the likelihood of repeating a grade with a dummy variable of a value of one if a student is one grade behind the median grade by state, sex, quarter of birth and age. This measure of grade retention includes students who

\footnotetext{
${ }^{12}$ The results are identical using the $1 \%$ sample for both years.

${ }^{13}$ To match dioceses and MSAs, we relied on the county composition of the diocese.

${ }^{14}$ According to the National Center for Education Statistics, approximately $80 \%$ of the total number of private schools in existence in the 1950s were Catholic (see also Kim (2011)).
} 
delayed entry into the school system and therefore it is, more accurately, a measure of gradefor-age. ${ }^{15}$ We compare cohorts of students who were 7-15 years old at the time of the 1970 US Census and entered school between 1961 and 1969 to the outcomes of students who were 7-15 years old at the time of the 1980 US Census and entered school between 1971 and 1979. This allows us to compare different cohorts of students living in the same areas and to control for both local area fixed effects, which account for time invariant characteristics, and cohort fixed effects, which capture systematic differences in school outcomes within a given cohort. Furthermore, we control for a set of time-varying characteristics of the MSA (e.g., current density of Catholic population, female labor force participation, population density, and teacher's education) that may be correlated with both the number of Catholic sisters and grade repetition. We restrict the sample to children living in identifiable MSA's, with no missing information on parental education and family income. After setting these restrictions, the sample included 841 and 958 children. We estimate the following linear probability model $^{16}$ :

$$
P_{i m t}=\beta_{0}+\theta N_{m t}+\beta_{1} X_{i m t}+\beta_{2} D_{m t}+\tau_{t}+\lambda_{m}+u_{i m t}
$$

where $P_{\text {imt }}$ is a dummy variable indicating whether individual $i$ of birth cohort $t$ goes to a parochial school in MSA $m .{ }^{17} N_{m t}$ denotes a measure of average exposure to Catholic sisters who are teachers throughout the schooling years of an individual $i$ in MSA $m$. Henceforth, we will use Catholic sisters to refer to Catholic sisters teaching in Catholic schools. ${ }^{18}$ This measure variates by birth cohort (we computed the starting school year based on quarter

\footnotetext{
${ }^{15}$ Alternatively, we measure grade retention by treating all children who turned 6 before October 1 as if they had entered first grade in the autumn of that year and children who turned 6 after October 1 as though they had entered school the following year. Our main results are substantially unchanged.

${ }^{16}$ As a robustness check, we estimate probit models for our main estimates. The results are substantially unchanged and available upon requests.

${ }^{17}$ As mentioned earlier, MSA-level data for Catholic sisters, teachers and the Catholic population were computed using diocesan data. Therefore, the term diocese and MSA will be used interchangeably in this paper.

${ }^{18}$ We alternatively use the total number of sisters (including those who were not teachers) in the diocese. The results flow in the same direction, as the two metrics are strongly correlated.
} 
of birth and age) and MSA. For example, if a 10-year-old student is observed in the 1970 Census in MSA $m$, he will be assigned the average number of Catholic sisters in MSA $m$ between 1967 and $1970 .{ }^{19} D_{m t}$ are MSA time-varying characteristics. $X_{i}$ are standard sociodemographic controls. $\tau_{t}$ and $\lambda_{m}$ are cohort and MSA fixed effects. To analyze the effects on school outcomes, we estimate the following model:

$$
Y_{i m t}=\alpha_{0}+\alpha_{1} P_{i m t}+\gamma_{1} X_{i m t}+\gamma_{2} D_{m t}+\tau_{t}+\lambda_{m}+\epsilon_{i m t}
$$

where $Y_{i m t}$ is an indicator of grade retention. In practice, we exploit within-MSA differences in the availability of Catholic sisters that created exogenous shifts in the likelihood of attending a parochial school to analyze the effects of Catholic schooling on grade repetition. We believe that conditioning on MSA time- varying characteristics and controlling for MSAs and cohort fixed effects shows that the sudden and sharp decline in the number of Catholic sisters that induced Catholic school closures across the country is an exogenous shock to Catholic schooling. ${ }^{20}$

\subsection{Evidence for the Exogeneity of the Instrument}

In an attempt to assess the validity of our instrumental strategy, in Table 2, we analyze the correlation between our instrument and individual observable characteristics (column 3). We then compare the coefficients reported in column 3 to the ones observed when considering the most recent instrument used in the literature (Cohen-Zada and Elder (2009), column 4) and the simple parochial schooling indicator (column 5). Columns 1 and 2 report the summary statistics of the main individual observables. In column 3, we present the standardized

\footnotetext{
${ }^{19}$ We followed the same method to compute analogue measures of exposure to lay teachers and total teachers in Catholic schools, Catholic schools, and Catholic population in the MSA.

${ }^{20} \mathrm{~A}$ potential concern is that grade retention policies may be different across Catholic and public schools. As we use a difference-in-difference approach, our identification strategy is not affected by persistent differences between the two types of schools. One could still be concerned that grade retention policies were correlated with the changes in the supply of religious teachers. However, it is worth noting that while the number of Catholic sisters teaching in schools declined dramatically, the school administration and direction remained largely in the hands of religious staff (Caruso, 2012).
} 
coefficients of separate regressions of the variables listed in the first column on the number of Catholic sisters, controlling for MSA and cohort fixed effects. In column 4, we repeat the same exercise for the instrumental variable proposed by Cohen-Zada and Elder (2009) and look at the relationship between observables and the historical share of Catholic population. ${ }^{21}$ We restrict the sample to 1980 and condition each regression for state fixed effects and current Catholic population to mimic the empirical strategy used by Cohen-Zada and Elder (2009). Finally, in column 5, we analyze the relationship between parochial schooling and the other observable characteristics. Column 5 confirms the significant selection on observable characteristics with parochial schooling associated with higher parental education, higher income and lower likelihood of minority status. The average number of Catholic sisters (column 3) is positively correlated with family income and parental education, suggesting some selection bias. As socio-economic status is positively associated with student outcomes, this may bias our estimates upward, and should therefore be interpreted as an upper bound. Family income and parental education are included as controls in all of our regressions. However, the coefficients on the other observables are non-significant. Furthermore, the absolute value of the coefficients is always lower with respect to the correlation between observables and both Catholic schooling (column 5) and the historical share of Catholics in the county (column 4). While this does not rule out that our estimates may still suffer from spurious correlation between unobservables and our instrument, Table 2 suggests that our instrumental variable may be less likely to suffer from selection on unobservables.

\footnotetext{
${ }^{21}$ Data on the share of Catholic population in 1980 are drawn from the Religious Congregation and Membership in the United States, while data for 1890 were taken from the American Religion Data Archive and originally collected by the US Census of Religious Bodies.
} 


\section{Main Results}

\subsection{Catholic School Supply and the Likelihood of Attending a Catholic School}

Table 3 illustrates the estimates for equations 1 (column 1) and 2 (columns 2-4). Each regression controls for a set of a child's characteristics, gender, race, Hispanic ethnicity, birth quarter, age dummies), family background (maternal and paternal age dummies, maternal and paternal education (4 groups), family income, MSA and cohort fixed effects, and a set of MSA time-varying characteristics, female labor force participation, teachers' education and Catholic population. ${ }^{22}$ We include a quadratic trend in all of our estimates. Standard errors are clustered at the MSA level. Column 1 reports the estimate of our first-stage regression. There is a positive and significant association between attending a parochial school and the number of sisters available in the different dioceses. The coefficient implies that a one standard deviation increase in the number of Catholic sisters (789.12) is associated with a $14 \%$ increase in the likelihood of attending a parochial school. The F-statistic of the first-stage is 14.84. We now move to the examination of the relationship between Catholic schooling and grade repetition. Column 2 reports the OLS estimate. Attending a parochial school is associated with an $11 \%$ reduction in the likelihood of repeating a grade. This finding is in line with previous evidence of a positive correlation between Catholic schooling and school outcomes. However, instrumenting parochial schooling with the cohort-MSA measure of exposure to Catholic sisters does not lead to evidence of significant effects on grade repetition. Column 3 reports the reduced form showing no significant relationship between the availability of nuns and the likelihood of repeating a grade. The 2SLS estimate (column

\footnotetext{
${ }^{22}$ Adding to this specification, teacher experience and the logarithm of teacher wages do not change the point estimate, but they do reduce the precision of our estimate. Female labor force participation and teacher education vary by census year. The female labor force participation rate in each MSA is calculated by dividing the number of employed women aged 15-64 by the total female population of the same age group. Teachers in each MSA were identified by industry (professional and related services - elementary and secondary schools) and occupation (elementary and secondary school teachers). The Catholic population is drawn from the Official Catholic Directory.
} 
4) is also non-significant and, if anything, suggests a negative (positive) effect of Catholic schooling on school outcomes (grade repetition). Although the standard errors are large, we reject the OLS estimate. ${ }^{23}$ Similar results are found when the sample is restricted to the four largest dioceses in the US (Chicago, Detroit, New York, and Los Angeles) using the number of Catholic sisters at the county level (see Table 4). Column 1 shows that one standard deviation in the number of Catholic sisters increases Catholic schooling by 35\%. The OLS and the reduced form coefficients (columns 2 and 3) on grade retention are substantially identical to the ones observed in Table 3. The 2SLS estimate in column 4 implies that Catholic schooling increases the likelihood of repeating the grade by 10 percentage points. ${ }^{24}$

\subsection{Is the Selection Implied by Our Results Plausible?}

The above findings suggest that the OLS estimates are driven by positive selection bias. To verify the plausibility of our results, we use the techniques of Altonji et al. (2005) and exploit the information about selection on the observables to gauge the role of selection bias and verify whether our IV estimates are consistent with it. In particular, in Table 5, we jointly estimate the following system of equations:

$$
\begin{gathered}
P=1\left(X^{\prime} \beta+u>0\right), \\
Y=1\left(X^{\prime} \gamma+\alpha P+\epsilon>0\right)
\end{gathered}
$$

We impose different values for $\rho$, the correlation between the error terms of the above equations. Column $1(\rho=0)$ presents the single-equation estimates. The marginal effect is sub-

\footnotetext{
${ }^{23}$ The Hausman test rejects the equality of the coefficients at the $10 \%$ level on the overall sample and at the $5 \%$ level when we restrict the sample to whites.

${ }^{24}$ We examined the sensitivity of our main estimate to the inclusion of additional time-varying controls, regional time trends, and region-year fixed effects. Including time-varying MSA information on teachers' wages and experience does not significantly affect the point-estimate with respect to the baseline result reported in column 1. However, the precision of the estimate is clearly affected because these variables are correlated with teachers' education. Including region-specific cohort trends, the point-estimate does not change substantially, but the confidence interval increases. These results are available upon request.
} 
stantially identical to the OLS estimate presented in Table 3, column 2. In columns 2-7 we illustrate how a modest amount of positive selection (small negative correlation between $\epsilon$ and $u$ ) is sufficient to explain away the positive effect of Catholic schooling and even reverse the sign. Column 8 reports the estimates obtained assuming that selection on the observables equals selection on unobservables. In other words, we assume that the projection of $P$ on $\epsilon$ equals its projection on the index of other determinants of $Y: \frac{\operatorname{Cov}(P, \epsilon)}{\operatorname{Var}(\epsilon)}=\frac{\operatorname{Cov}\left(P, X^{\prime} \gamma\right)}{\operatorname{Var}\left(X^{\prime} \gamma\right)}$. Altonji et al. (2005) justify the equal selection assumption by arguing that for large datasets used for different purposes, the available information can be thought of as a random subset of the determinants of a particular outcome under study. ${ }^{25}$ Following this approach, we identify a lower bound for the effects of Catholic schooling. In practice, we estimate a bivariate probit model and maximize the likelihood imposing $\rho=\frac{\operatorname{Cov}\left(X^{\prime} \beta, X^{\prime} \gamma\right)}{\operatorname{Var}\left(X^{\prime} \gamma\right)}$. The estimate of $\alpha$ implies a large and negative effect of parochial schooling on grade repetition. Under the assumption of equality of selection on observables and unobservables, the strong and positive (negative) correlation between observable determinants of student outcomes (grade repetition) and Catholic schooling results in a strong and positive correlation with the unobservables, implying a large positive bias in the OLS bias. In other words, correcting for the bias using Altonji et al. (2005) method predicts an even more negative effect of Catholic schooling on grade repetition than the effect found using our IV. Using a more informal approach, we estimate that if selection on unobservables was less than half as strong (approximately 40\%) as that found on a limited set of observables, the effect of Catholic schooling would be explained away. ${ }^{26}$ Overall, this sensitivity analysis confirms that the OLS estimates are driven by selection bias and that Catholic schooling increases the likelihood of grade repetition.

\footnotetext{
${ }^{25}$ Note that this is an extreme assumption because datasets are designed to answer particular questions and researchers do not choose their controls randomly. Therefore, selection on unobservables is likely to be less than selection on observables. However, for large datasets, such as the US Census, the actual selection on unobservables may be closer to the selection implied by the equal selection assumption than to the one that uses smaller longitudinal surveys containing a rich set of individual characteristics (e.g., NLSY79, NELS:88 etc.).
}

${ }^{26}$ Altonji et al. (2005) show that if the bias in a probit is close to the bias in OLS, then

$$
\operatorname{plim} \quad \hat{\alpha}=\alpha+\frac{\operatorname{Cov}(\tilde{P}, \epsilon)}{\operatorname{Var}(\tilde{P})}=\alpha+\frac{\operatorname{Var}(P)}{\operatorname{Var}(\tilde{P})[E(\epsilon \mid P=1)-E(\epsilon \mid P=0)}
$$




\subsubsection{The Effects Across Socio-Demographic Groups}

Previous studies found larger positive effects of Catholic schooling on minority students. In Table 6, we report the 2SLS estimates by race, ethnicity and poverty level. Column 1 replicates the estimate of column 4 in Table 3 . In column 2, we restrict the sample to whites. The 2SLS coefficient is still not significantly different from zero, but the estimate is more precisely estimated. Focusing on non-Hispanic whites, the coefficient becomes significant and suggests that parochial schooling increases the likelihood of repeating a grade by $20 \%$. The sign of the coefficient becomes negative when we look at minorities. While the large variance does not allow for making strong inferences, the direction of the effect appears to be consistent with previous studies on Catholic schooling and minorities. The coefficient is positive and significant when we analyze children hailing from families above the median poverty level (i.e., of higher socio-economic status), and the effect is less precisely estimated for children of families with lower socio-economic status.

\subsection{Did the Shock Affect the Quality of Catholic Schools?}

A potential threat to the validity of the exogeneity assumption is the fact that the shock to the supply of Catholic sisters may have had an impact not only on the supply of Catholic schools and tuition costs but also on the average quality of surviving Catholic schools. It is reasonable to assume that the sudden decline in the number of Catholic sisters also affected the quality of Catholic school personnel. The literature suggests that the higher dedication and vocational motivation of Catholic school teachers is one mechanism behind the positive

where $\tilde{P}$ is the residual from a regression of $P$ on the set of observable controls $X$. Under the assumption that observable and unobservable determinants of student outcomes have the same relationship with Catholic schooling, $\frac{E(\epsilon \mid P=1)-E(\epsilon \mid P=0)}{\operatorname{Var}(\epsilon)}=\frac{E\left(X^{\prime} \gamma \mid P=1\right)-E\left(X^{\prime} \gamma \mid P=0\right)}{\operatorname{Var}\left(X^{\prime} \gamma\right)}$. Therefore,

$$
\operatorname{plim} \hat{\alpha}=\alpha+\frac{\operatorname{Cov}(\tilde{P}, \epsilon)}{\operatorname{Var}(\tilde{P})}=\alpha+\frac{E\left(X^{\prime} \gamma \mid P=1\right)-E\left(X^{\prime} \gamma \mid P=0\right)}{\operatorname{Var}\left(X^{\prime} \gamma\right)}
$$

The ratio between the unconstrained estimate of $\alpha$ and the estimated selection bias can then be used to measure how strong the selection on unobserved characteristics should be relative to the selection on observables for explaining all of the effects of parochial schooling. 
effects of Catholic schooling (Neal, 1997). In addition to higher motivation, Kim (2011) shows that religious personnel were, on average, more educated and more experienced. The Notre Dame Survey on American Catholic Schools of 1966 provides aggregate descriptives that confirm the relative higher experience, education and work satisfaction of religious teachers compared to lay teachers in Catholic schools. In particular, we know that $49 \%$ of Catholic sisters had a Masters degree compared to only $19 \%$ of lay teachers. Furthermore, sisters were often required to attend educational and training programs. Koedel (2008) shows that teacher quality and education have significant effects on graduation outcomes. If we believe that the higher education and motivation of sisters had a significant and positive impact on the student outcomes, we should expect our reduced-form coefficient to be upward-biased. We document the evidence of a negative association between the share of religious teachers and the likelihood of grade repetition in Catholic schools (see Table 7). Our results show that the ratio of religious teachers to lay teachers in Catholic schools (or the share of Catholic sisters among Catholic school teachers) is negatively associated with the likelihood of grade repetition among students attending Catholic schools (see column 1). In particular, we find that a one standard deviation in the sister-lay teacher ratio is associated with a $3 \%$ decline in grade repetition. This is equivalent to a $21 \%$ effect with respect to the average grade repetition rate among parochial school students (14.7\%). The coefficient becomes nonsignificant when focusing on non-Hispanic whites (column 3) and is large and significant for minorities (column 4). The point-estimate implies that a one standard deviation increase in the sister-lay teacher ratio is associated with a $57 \%$ decrease in the likelihood of repeating a grade for minority students attending parochial schools. Similarly, the coefficient is nonsignificant when looking at students whose families are above the median poverty level (i.e., of higher socio-economic status, column 5) but negative and significant for students of lower socio-economic status (- 23\%, column 6). These results are in line with the idea that more qualified and motivated teachers may be more productive for disadvantaged students (Kim, 2011; Koedel, 2008). The results also help explain the positive results found by Neal (1997) 
when looking at the effect of Catholic schools on urban minorities. Exploring the effects of the Second Vatican Council on the quality of teachers in Catholic schools goes well beyond the main purpose of this paper and would require additional micro-level data on teachers and school characteristics (see Kim (2011)). However, it is important to discuss how the effects of the Second Vatican Council on teacher quality may affect the validity of our identification strategy. Because we argued that the higher quality of Catholic sister teachers had a significant and positive impact on student outcomes, we expect our reduced-form coefficient to be upward-biased. Therefore, because we find a null or negative effect, we interpret our IV estimates as plausibly identifying a lower bound on the effects of Catholic schooling on grade repetition.

\subsubsection{Other Educational Outcomes}

In Table 8, we investigate the reduced-form relationship between the average number of Catholic sisters and other measures of educational attainment. Unfortunately, the lack of information on the Catholic school attendance of former students prevents us from estimating the treatment effects of Catholic schooling. Similar to the approach used in Section 3.3, we compute the average number of nuns available to each individual living in a different diocese during his schooling years. In column 1, we consider the relationship between the exposure to Catholic sisters and the likelihood of being enrolled in school at the age of post-compulsory education, i.e., upon attaining the legal dropout age. ${ }^{27}$ The coefficient is positive but highly insignificant. Column 2 considers the effect of dropping out of high school. We use the standard definition and consider individuals between 16 and 24 years of age who did not obtain high school diplomas and were not enrolled in school as dropouts. We restrict the sample to individuals who resided in the same MSA for the 5 years preceding the survey. The coefficient is only marginally significant and points to a positive relationship between the number of Catholic sisters available during a students schooling years and the likelihood

\footnotetext{
${ }^{27}$ States differ in their compulsory schooling requirement. We follow Angrist and Krueger (1991) in defining the legal dropout age, which is a combination of compulsory schooling laws and school starting age.
} 
of being a high school dropout. In column 3, we examine the high school graduation rates of individuals between 18 and 23 years of age. Similarly, in column 4, we look at the likelihood of having attended some college for individuals between 18 and 23 years of age. We do not find evidence of significant effects on any of these educational outcomes. ${ }^{28}$ However, these estimates should be considered with caution because by looking at the outcomes of older cohorts, we substantially increase the selectivity in the sample and compromise the ability of controlling for parental background.

\section{Conclusion}

A large literature has investigated the relationship between Catholic schooling and student outcomes. Most of the previous studies have found positive effects, but the causality has long been questioned. This paper proposes a new identification strategy for assessing the effects of Catholic schooling on student outcomes. We exploit an exogenous shock to the number of Catholic sisters and show that the positive correlation between Catholic schooling and student outcomes is explained entirely by selection bias.

We show that the unexpected shock to the supply of Catholic sisters, induced by the changes sparked by the Second Vatican Council, affected the number of Catholic schools and, in turn, the likelihood of children attending Catholic schools. Additionally, we present evidence that compared to previous instruments used in the literature, our instrumental strategy is less likely to violate the exclusion restriction. We confirm the previous findings of a positive correlation between Catholic schooling and educational outcomes. However, using our instrument to identify the causal effects of Catholic schooling on grade repetition, we find no evidence of positive effects and reject the OLS estimates. If anything, our estimates imply that Catholic schooling increases the likelihood of repeating a grade. These results are similar to those found by Elder and Jepsen (2013) using more recent data on primary

\footnotetext{
${ }^{28}$ Note that when further restricting the sample to individuals born in the same state in which they currently reside, the results do not change significantly. However, the coefficient on high school dropouts becomes insignificant.
} 
schools. To verify the plausibility of our results, we use the techniques of Altonji et al. (2005) and show that even a modest degree of selection on unobservable characteristics is sufficient to eliminate and reverse the sign of Catholic schooling. We find no evidence of positive effects when analyzing different measures of educational attainment using reducedform relationships.

A natural extension of this study would be to adopt our identification strategy to analyze the effects of private school competition on educational attainment. Further research could also use this approach to reassess the effects of Catholic schooling on labor market outcomes and behaviors. Finally, along with parochial education, Catholic sisters were largely involved in health care (Sack, n.d.). Future studies could analyze how the drastic decline of religious orders affected American hospitals.

\section{References}

Alberigo, Giuseppe (2006) A Brief History of Vatican II (Maryknoll, NY: Orbis Books)

Altonji, Joseph G., Todd E. Elder, and Christopher R. Taber (2005) 'Selection on observed and unobserved variables: assessing the effectivenemss of Catholic schools.' Journal of Political Economy 113, 151-184

Angrist, Joshua D., and Alan B. Krueger (1991) 'Does compulsory school attendance affect schooling and earinings.' The Quarterly Journal of Economics CVI(4), 979-1014

Berman, Eli, Laurence R. Iannaccone, and Giuseppe Ragusa (2012) 'From empty pews to empty cradles: Fertility decline among European Catholics.' NBER Working Paper

Bryk, Anthony, Valerie E. Lee, and Peter Blakeley Holland (1993) Catholic Schools and the Common Good (Cambridge, MA: Harvard University Press)

Carbonaro, William (2006) 'Public-private differences in achievement among kindergarten 
students: Differences in learning opportunities and student outcomes.' American Journal of Education 113(1), 31-66

Caruso, Michael P. SJ (2012) When the Sisters Said Farewell (Lanham, MD: Rowman \& Littlefield Education)

Cohen-Zada, Danny, and Todd Elder (2009) 'Historical religious concentration and the effects of Catholic schooling.' Journal of Urban Economics 66, 65-74

Dolan, James P. (1992) The American Catholic Experience (Garden City, N.Y.: University of Notre Dame Press)

Ebaugh, Helen Rose (1993) 'The growth and decline of Catholic religious orders of women worldwide: The impact of women's opportunity structures.' Journal for the Scientific Study of Religion 32(4), 68-75

Elder, Todd, and Christopher Jepsen (2013) 'Are Catholic primary schools more effective than public primary schools?' Journal of Urban Economics

Fialka, John J. (2003) Sisters: Catholic Nuns and the Making of America (New York, NY: St. Martin's Press)

Finke, Roger, and Rodney Stark (2005) The Churching of America: 1776-2005 (New Brunswick, NJ: Rutgers University Press)

Hesburgh, Theodore, Frederick G. Hochwalt, and George N. Shuster (1966) The Notre Dame Study of Catholic Elementary and Secondary Schools in the United States (Notre Dame, IN: University of Notre Dame Press)

Kim, Young-Joo (2011) 'Catholic schools or school quality? The effects of Catholic schools on labor market outcomes.' Economics of Education Review 30, 546-558

Koedel, Cory (2008) 'Teacher quality and dropout outcomes in a large, urban school district.' Journal of Urban Economics 64, 560-572 
Koob, C. Albert, and Russell Shaw (1970) S.O.S for Catholic Schools (New York, NY: Holt, Rinehart and Winston)

Lankford, R.H., and H.S. Lee (1995) 'An analysis of elementary and secondary school choice.' Journal of Urban Economics (38), 236-251

Lubienski, Christopher, Corinna Crane, and Sarah Thule Lubienski (2009) 'What do we know about school effectiveness? Academic gains in public and private schools.' Phi Delta Kappan 89(9), 689-685

Neal, Derek (1997) 'The effects of Catholic secondary schooling on educational achievement.' Journal of Labor Economics 15(1), 98-123

Neal, Marie Augusta (1984) Catholic sisters in transition: From the 1960s to the 1980s (Wilmington, DE: Michael Glazier)

Oreopoulos, Philippe, Marianne Page, and Ann Stevens (2006) 'The intergenerational effects of compulsory schooling.' Journal of Labor Economics 24(4), 729-760

Reardon, Sean F., Jacob F. Cheadle, and Joseph P. Robinson (2009) 'The effects of Catholic schooling on math and reading development in kindergarten through fifth grade.' Journal of Research on Educational Effectiveness 2(1), 45-87

Sack, Kevin "Nuns, a "dying breed," fade from ledership roles at Catholic hospitals.' The New York Times, 20 August 2011. Available: http://www.nytimes.com/2011/08/21/us/21nuns.html [Last accessed: 5 November $2013]$

Shepard, Lorrie A., and Mary L. Smith (1989) Flunking grades: Research and policies on retention (New York, NY: Falmer)

Stark, Rodney, and Roger Finke (2000) 'Catholic religious vocations: Decline and revival.' Review of Religious Research 42, 125-145 
Wilde, Melissa (2007) Vatican II: A Sociological Analysis of Religious Change (Princeton, NJ: Pricenton University Press) 
Figure 1: Human Assets in the American Catholic Church, 1950-1985

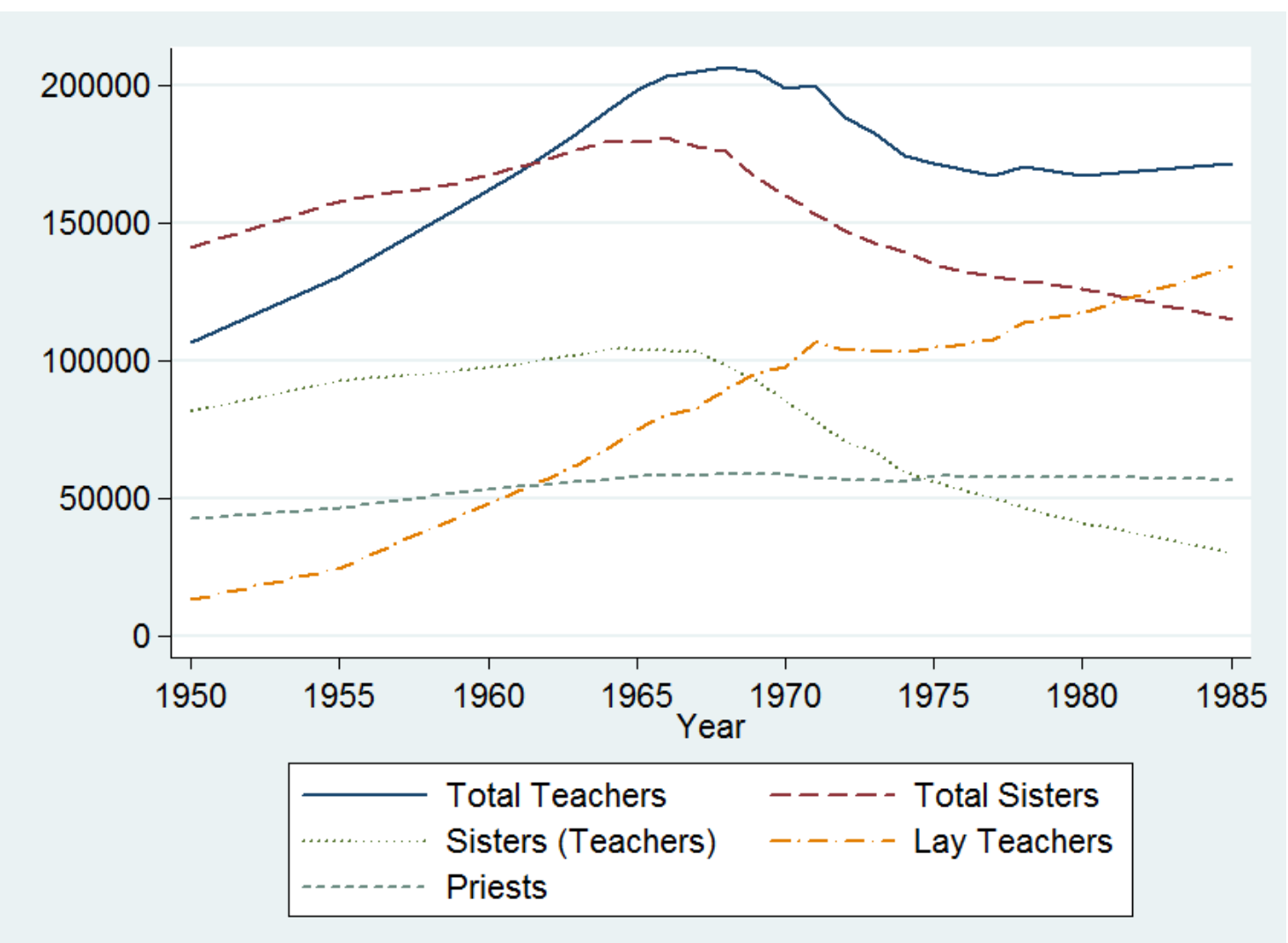

Notes - Number of Sisters, Priests, Teachers in Catholic Schools, Sister Teachers, Lay Teachers. Source: Official Catholic Directory 1950-1985. 
Figure 2: The Decline of Catholic Sisters and Catholic Schools Across US

\section{Catholic Teachers and Catholic Schools Before and After the Second Vatican Council}
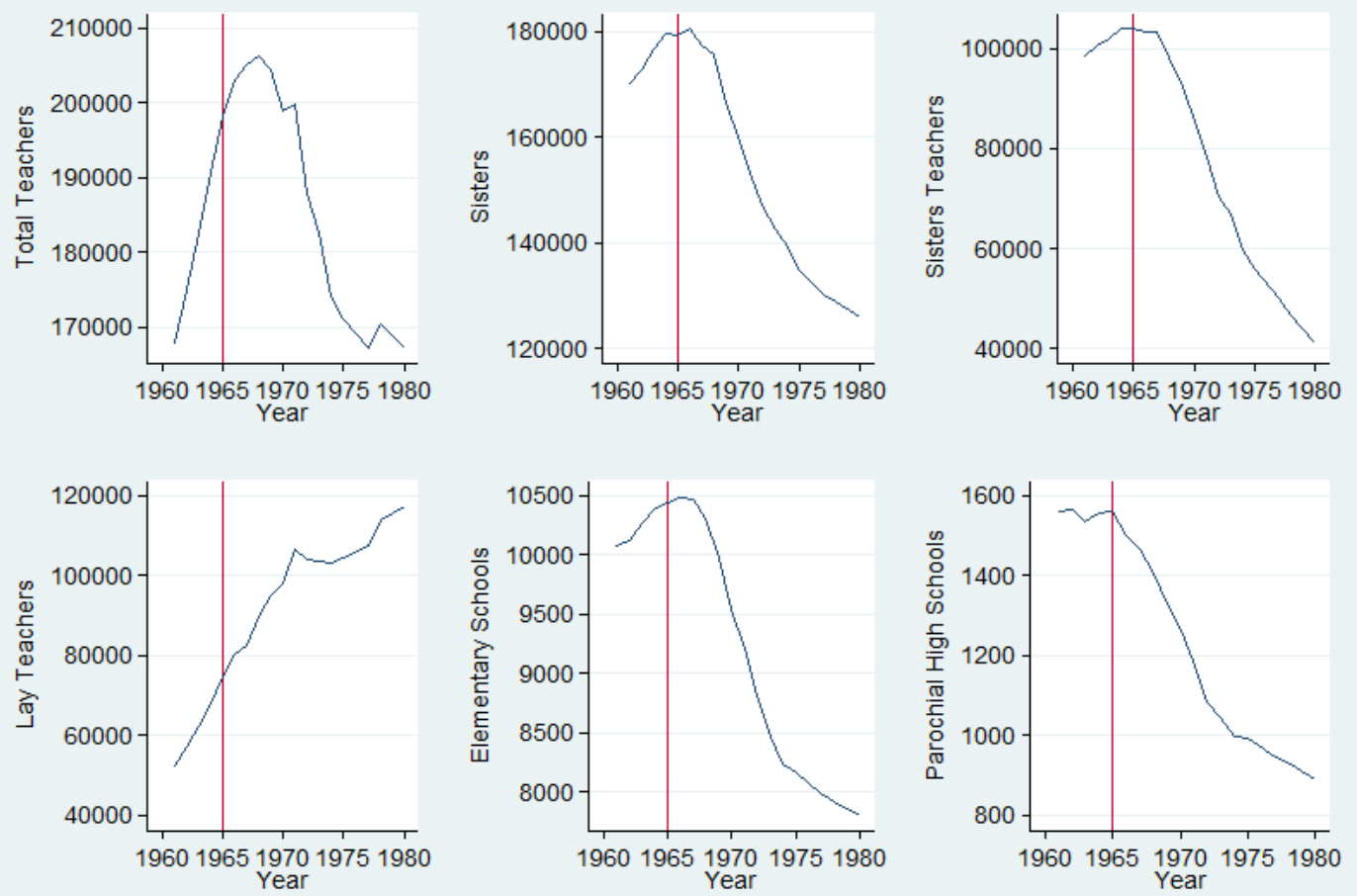

Notes - Source: Official Catholic Directory 1950-1985. 
Figure 3: The Decline of Catholic Sisters and Catholic Schools Across Liberal and Conservative Dioceses

Catholic Teachers and Schools per Catholic (in thousand)
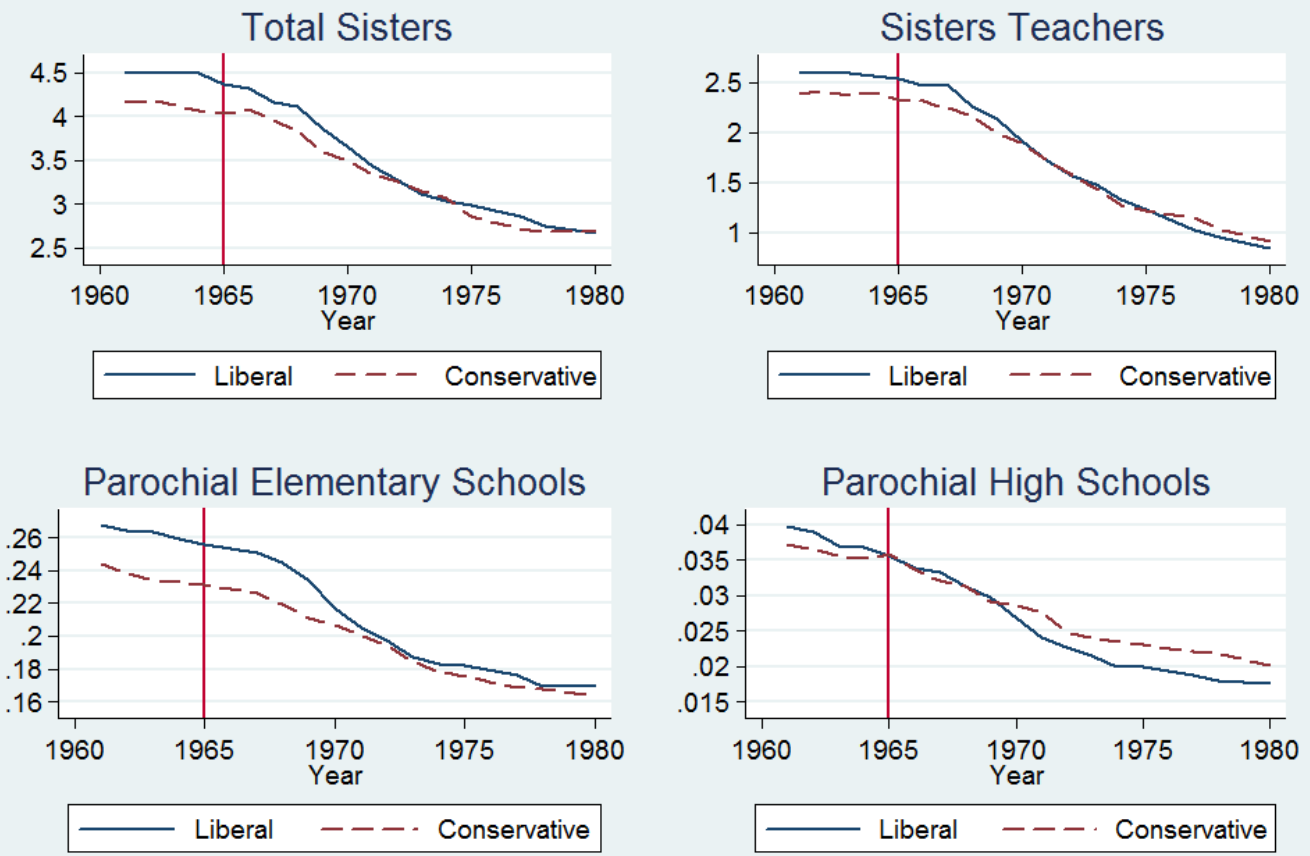

Notes - Source: Official Catholic Directory 1950-1985. Voting records of Bishops at Vatican II (collected by Melissa Wilde, 2007). 
Figure 4: The Decline of Catholic Sisters Across US States (1966-1980)

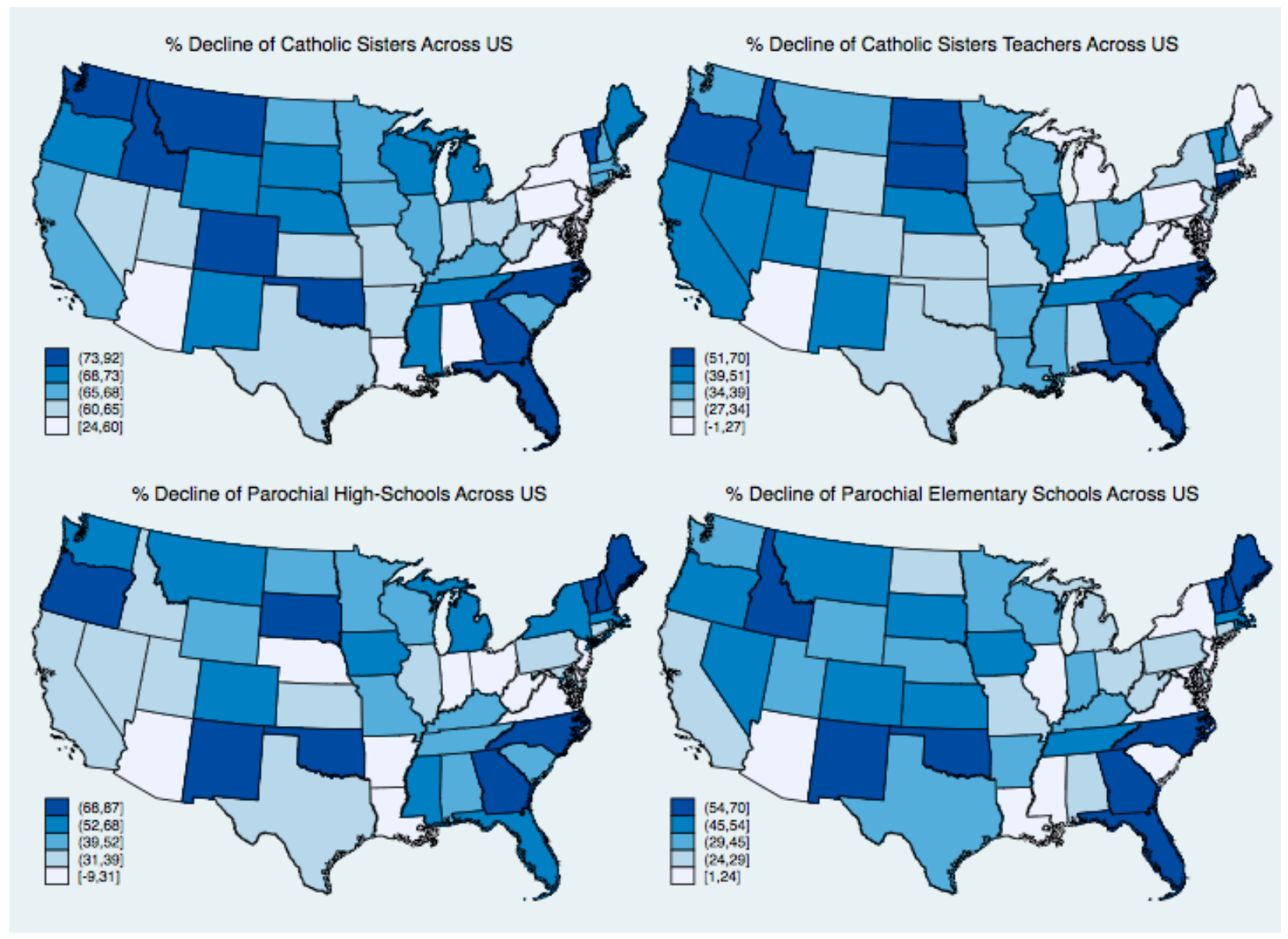

Notes - Source: Official Catholic Directory 1966 and 1980. States are classified in 5 categories. The darker the blue the higher the decline in the number of Catholic sisters and parochial schools between 1966 and 1980 . 
Table 1: Heterogeneity in the Vatican II Shock across US dioceses

\begin{tabular}{|c|c|c|c|c|}
\hline & $\begin{array}{c}(1) \\
\text { Sisters } \\
\text { per } 1,000 \text { Catholics }\end{array}$ & $\begin{array}{c}(2) \\
\text { Sisters Teachers } \\
\text { per 1,000 Catholics }\end{array}$ & $\begin{array}{c}(3) \\
\text { Sisters } \\
\text { per } 1,000 \text { Catholics }\end{array}$ & $\begin{array}{c}(4) \\
\text { Sisters Teachers } \\
\text { per 1,000 Catholics }\end{array}$ \\
\hline Vatican II & $\begin{array}{c}-1.832^{* * *} \\
(0.066)\end{array}$ & $\begin{array}{c}-1.474^{* * *} \\
(0.042)\end{array}$ & $\begin{array}{c}-1.858^{* * *} \\
(0.066)\end{array}$ & $\begin{array}{c}-1.489^{* * *} \\
(0.042)\end{array}$ \\
\hline Vatican II * conservative diocese & $\begin{array}{l}0.218^{*} \\
(0.114)\end{array}$ & $\begin{array}{c}0.163^{* *} \\
(0.073)\end{array}$ & $\begin{array}{l}0.192^{*} \\
(0.114)\end{array}$ & $\begin{array}{c}0.147^{* *} \\
(0.073)\end{array}$ \\
\hline $\begin{array}{l}\text { Vatican II * most conservative } \\
\text { diocese }\end{array}$ & & & $\begin{array}{c}0.913^{* * *} \\
(0.281)\end{array}$ & $\begin{array}{c}0.540^{* * *} \\
(0.179)\end{array}$ \\
\hline Diocese fixed effect & YES & YES & YES & YES \\
\hline Observations & 2,307 & 2,307 & 2,307 & 2,307 \\
\hline R-squared & 0.328 & 0.439 & 0.332 & 0.441 \\
\hline
\end{tabular}

Notes - Source: Official Catholic Directory (1955-1985) and voting records of Bishops at Vatican II collected by Wilde (2007) from the Vatican Secret Archive (Archivio Segreto Vaticano). The sample is restricted to the 105 dioceses for which we have information on Bishop's vote at the Second Vatican Council. 
Table 2: IVs and Individual Observable Characteristics

\begin{tabular}{|c|c|c|c|c|c|}
\hline & (1) & (2) & (3) & $\begin{array}{c}(4) \\
\text { Univariate regressions }\end{array}$ & (5) \\
\hline $\begin{array}{l}\text { Census } \\
\text { Variables }\end{array}$ & $\begin{array}{l}\text { 1970-1980 } \\
\text { Mean }\end{array}$ & $\begin{array}{l}\text { 1970-1980 } \\
\text { S.d. }\end{array}$ & $\begin{array}{c}1970-1980 \\
\text { Sisters (in thousands) }\end{array}$ & $\begin{array}{c}\text { (Cohen-Zada \& Elder, 2009) } \\
1980 \\
\text { pcath1890/pcath1980 }\end{array}$ & $\begin{array}{l}\text { 1970-1980 } \\
\text { Enrolled in a parochial school }\end{array}$ \\
\hline $\begin{array}{l}\text { Grade repetition } \\
\text { Enrolled in a parochial school } \\
\text { Male } \\
\text { Black } \\
\text { Hispanic } \\
\text { Mother's education } \\
\text { Father's education } \\
\text { Log (family income) }\end{array}$ & $\begin{array}{l}0.18 \\
0.14 \\
0.51 \\
0.11 \\
0.10 \\
2.18 \\
2.38 \\
9.40\end{array}$ & $\begin{array}{l}0.38 \\
0.35 \\
0.50 \\
0.31 \\
0.29 \\
0.94 \\
1.11 \\
0.64\end{array}$ & $\begin{array}{c}-0.002 \\
\mathbf{0 . 0 6 3} * * * \\
0.002 \\
-0.001 \\
-0.021 \\
\mathbf{0 . 0 2 3}^{* * *} \\
\mathbf{0 . 0 2 9}^{* * *} \\
\mathbf{0 . 0 6 8}^{* * *}\end{array}$ & $\begin{array}{c}0.017^{*} \\
0.0101^{* * *} \\
0.003 \\
0.118^{* *} \\
0.102^{*} \\
-0.053^{*} \\
-0.068^{* *} \\
-0.078^{* *}\end{array}$ & $\begin{array}{l}-0.043^{* * *} \\
1.000^{* * *} \\
-0.014^{* * *} \\
-0.060^{* * *} \\
-0.013^{* *} \\
0.180^{* * *} \\
0.220^{* * *} \\
0.137^{* * *}\end{array}$ \\
\hline
\end{tabular}


Table 3: Sisters, Catholic Schooling and School Outcomes

\begin{tabular}{|c|c|c|c|c|}
\hline Dependent variable & $\begin{array}{c}(1) \\
\text { First Stage } \\
\text { Enrolled in a Parochial School } \\
\end{array}$ & $\begin{array}{c}(2) \\
\text { OLS } \\
\text { Grade Repetition }\end{array}$ & $\begin{array}{c}(3) \\
\text { Reduced-Form } \\
\text { Grade Repetition }\end{array}$ & $\begin{array}{c}\text { (4) } \\
\text { IV } \\
\text { Grade Repetition } \\
\end{array}$ \\
\hline Sisters (in thousand) & $\begin{array}{c}0.023^{* * *} \\
(0.006)\end{array}$ & & $\begin{array}{c}0.005 \\
(0.004)\end{array}$ & \\
\hline Enrolled in a parochial school & & $\begin{array}{c}-0.020^{* * *} \\
(0.003)\end{array}$ & & $\begin{array}{c}0.255 \\
(0.167)\end{array}$ \\
\hline $\begin{array}{l}\text { Observations } \\
\text { First-stage F }(1,121)\end{array}$ & $\begin{array}{c}841,958 \\
14.84\end{array}$ & 841,958 & 841,958 & 841,958 \\
\hline $\begin{array}{l}\text { Mean of dependent variable } \\
\text { s.d. }\end{array}$ & $\begin{array}{l}0.139 \\
0.346\end{array}$ & $\begin{array}{l}0.176 \\
0.381\end{array}$ & $\begin{array}{l}0.176 \\
0.381\end{array}$ & $\begin{array}{l}0.176 \\
0.381\end{array}$ \\
\hline
\end{tabular}

Notes - Data are drawn from the 1970 and 1980 US Census. The sample is restricted to children 7-15 years old. All estimates include controls for a set of child's characteristics (gender, race, Hispanic ethnicity, birth quarter, age dummies), family background (maternal and paternal age (quadratic), maternal and paternal education (4-groups), family income), MSA and cohort fixed effects, and a set of MSA time varying characteristics (female labor force participation, and teachers' education). Standard errors are clustered at the MSA level. 
Table 4: Sisters, Catholic Schooling and School Outcomes, 4 Largest Dioceses

\begin{tabular}{|c|c|c|c|c|}
\hline Dependent variable & $\begin{array}{c}(1) \\
\text { First Stage } \\
\text { Enrolled in a Parochial School }\end{array}$ & $\begin{array}{c}(2) \\
\text { OLS } \\
\text { Grade Repetition }\end{array}$ & $\begin{array}{c}(3) \\
\text { Reduced-Form } \\
\text { Grade Repetition }\end{array}$ & $\begin{array}{c}\text { (4) } \\
\text { IV } \\
\text { Grade Repetition }\end{array}$ \\
\hline Sisters (in thousand) & $\begin{array}{c}0.067^{* *} \\
(0.025)\end{array}$ & & $\begin{array}{c}0.007 \\
(0.005)\end{array}$ & \\
\hline $\begin{array}{l}\text { Observations } \\
\text { First-stage } F(1,7)\end{array}$ & $\begin{array}{c}117,376 \\
7.17\end{array}$ & 117,376 & 117,376 & 117,376 \\
\hline $\begin{array}{l}\text { Mean of dependent variable } \\
\text { s.d. }\end{array}$ & $\begin{array}{l}0.209 \\
0.406\end{array}$ & $\begin{array}{l}0.173 \\
0.378\end{array}$ & $\begin{array}{l}0.173 \\
0.378\end{array}$ & $\begin{array}{l}0.173 \\
0.378\end{array}$ \\
\hline
\end{tabular}

Notes - Data are drawn from the 1970 and 1980 US Census. The sample is restricted to children 7-15 years old living in counties belonging to the 4 largest U.S. dioceses: Chicago, Detroit, New York, and Los Angeles. All estimates include controls for a set of child's characteristics (gender, race, Hispanic ethnicity, birth quarter, age dummies), family background (maternal and paternal age (quadratic), maternal and paternal education (4-groups), family income), county and cohort fixed effects, and a set of county time varying characteristics (female labor force participation, teachers'education and Catholic population). Standard errors are clustered at the county level. 


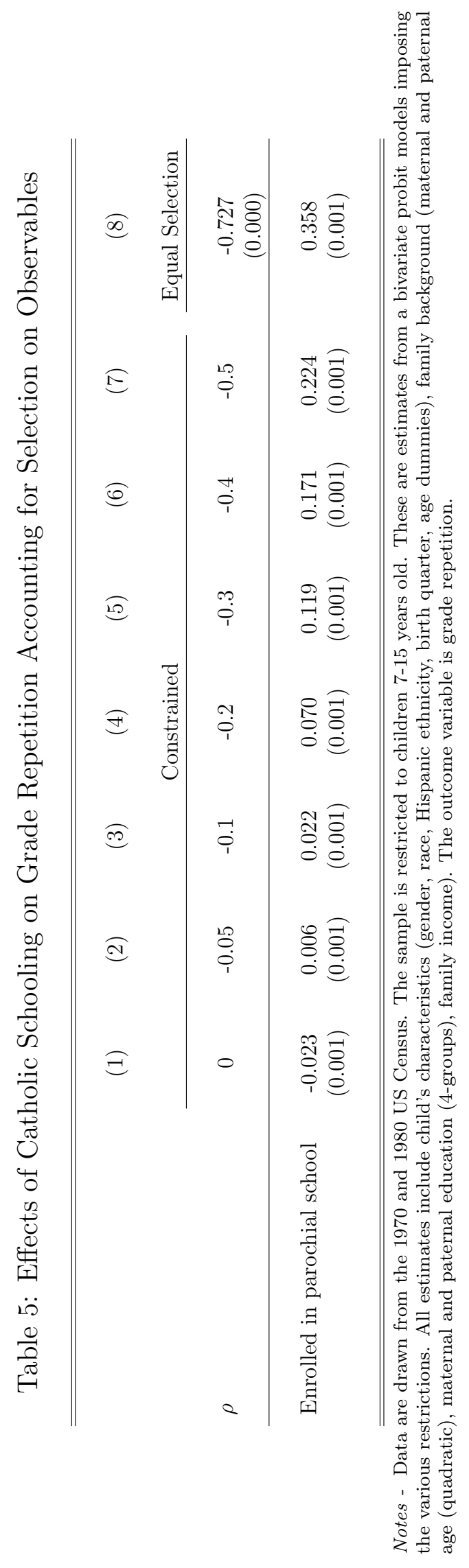




\section{Table 6: Catholic Schooling and Grade Repetition, by Socio-Demographic Groups}

\begin{tabular}{lcccccc}
\hline \hline & $\begin{array}{c}(1) \\
\text { All }\end{array}$ & $\begin{array}{c}(2) \\
\text { Whites }\end{array}$ & $\begin{array}{c}(3) \\
\text { Non-Hispanic } \\
\text { Whites }\end{array}$ & $\begin{array}{c}(4) \\
\text { Minorities }\end{array}$ & $\begin{array}{c}(5) \\
\text { Below median } \\
\text { poverty level }\end{array}$ & $\begin{array}{c}\text { Above median } \\
\text { poverty level }\end{array}$ \\
\hline Enrolled in a parochial school & 0.253 & 0.170 & $0.213^{* *}$ & -0.0509 & $0.304^{* *}$ & 0.255 \\
& $(0.167)$ & $(0.108)$ & $(0.093)$ & $(0.321)$ & $(0.143)$ & 414,058 \\
Observations & 841,958 & 751,302 & 671,872 & 170,086 & 427,900 \\
Mean of dependent Variable & 0.176 & 0.173 & 0.163 & 0.227 & 0.138 & 0.213 \\
s.d. & 0.381 & 0.378 & 0.369 & 0.419 & 0.345 & 0.409 \\
\hline \hline
\end{tabular}

Notes - Data are drawn from the 1970 and 1980 US Census. The sample is restricted to children 7-15 years old. All estimates include controls for a set of child's characteristics (gender, race, Hispanic ethnicity, birth quarter, age dummies), family background (maternal and paternal age (quadratic), maternal and paternal education (4-groups), family income), MSA and cohort fixed effects, and a set of MSA time varying characteristics (female labor force participation, and teachers' education). Standard errors are clustered at the MSA level. 


\section{Table 7: Sisters-Lay Teachers Ratio and Grade Repetition in Catholic Schools}

\begin{tabular}{lcccccc}
\hline \hline & $(1)$ & $(2)$ & $(3)$ & $(4)$ & $(5)$ & $\begin{array}{c}(6) \\
\text { All }\end{array}$ \\
& Whites & $\begin{array}{c}\text { Non-Hispanic } \\
\text { Whites }\end{array}$ & $\begin{array}{c}\text { Minorities } \\
\text { Below median } \\
\text { poverty level }\end{array}$ & $\begin{array}{c}\text { Above median } \\
\text { poverty level }\end{array}$ \\
\hline Sisters-Lay Teachers Ratio & $\begin{array}{r}-0.030^{* *} \\
(0.015)\end{array}$ & $\begin{array}{c}-0.027^{*} \\
(0.015)\end{array}$ & $\begin{array}{c}-0.022 \\
(0.015)\end{array}$ & $\begin{array}{c}-0.111^{* * *} \\
(0.027)\end{array}$ & $\begin{array}{c}-0.020 \\
(0.018)\end{array}$ & $\begin{array}{c}-0.041^{* * *} \\
(0.015)\end{array}$ \\
& 117,148 & 110,578 & 100,803 & 16,345 & 64,217 & 52,931 \\
Observations & & & & & & \\
Mean of dependent variable & 0.147 & 0.144 & 0.137 & 0.192 & 0.125 & 0.168 \\
s.d. & 0.345 & 0.344 & 0.338 & 0.384 & 0.328 & 0.364 \\
\hline \hline
\end{tabular}

Notes - Data are drawn from the 1970 and 1980 US Census. The sample is restricted to children 7-15 years old enrolled in parochial schools. All estimates include controls for a set of child's characteristics (gender, race, Hispanic ethnicity, birth quarter, age dummies), family background (maternal and paternal age (quadratic), maternal and paternal education (4-groups), family income), MSA and cohort fixed effects, and a set of MSA time varying characteristics (female labor force participation, teachers' education, and Catholic population). Minorities include blacks and Hispanics. Standard errors are clustered at the MSA level. 


\section{Table 8: Other Outcomes - Reduced Form Analysis}

\begin{tabular}{|c|c|c|c|c|}
\hline Dependent Variable & $\begin{array}{l}\text { (1) } \\
\text { Dropout at post- } \\
\text { compulsory age }\end{array}$ & $\begin{array}{c}(2) \\
\text { HS dropout } \\
\text { (age 16-24) }\end{array}$ & $\begin{array}{c}\quad(3) \\
\text { HS graduation } \\
\text { (age 18-23) }\end{array}$ & $\begin{array}{c}(4) \\
\text { Some College } \\
\text { (age 18-23) }\end{array}$ \\
\hline Sisters (in thousands) & $\begin{array}{c}0.008 \\
(0.006)\end{array}$ & $\begin{array}{l}0.007^{*} \\
(0.004)\end{array}$ & $\begin{array}{c}0.001 \\
(0.007)\end{array}$ & $\begin{array}{l}-0.011 \\
(0.011)\end{array}$ \\
\hline Observations & 100,161 & 340,612 & 253,128 & 253,128 \\
\hline $\begin{array}{l}\text { Mean of dependent Variable } \\
\text { s.d. }\end{array}$ & $\begin{array}{l}0.105 \\
0.306\end{array}$ & $\begin{array}{l}0.150 \\
0.357\end{array}$ & $\begin{array}{l}0.754 \\
0.431\end{array}$ & $\begin{array}{l}0.323 \\
0.468\end{array}$ \\
\hline
\end{tabular}

Notes - Data are drawn from the 1970 and 1980 US Census. All estimates include controls for a set of individual's characteristics (gender, race, Hispanic ethnicity, birth quarter, age dummies), MSA and cohort fixed effects, and a set of MSA time varying characteristics (female labor force participation, teachers' education and Catholic population). Columns 2-4 further restrict the sample to individuals who were residing in the same metropolitan area 5 years before the Census. Standard errors are clustered at the MSA level. 


\section{Appendix}

Figure 5: Extract from the Official Catholic Directory, 1965

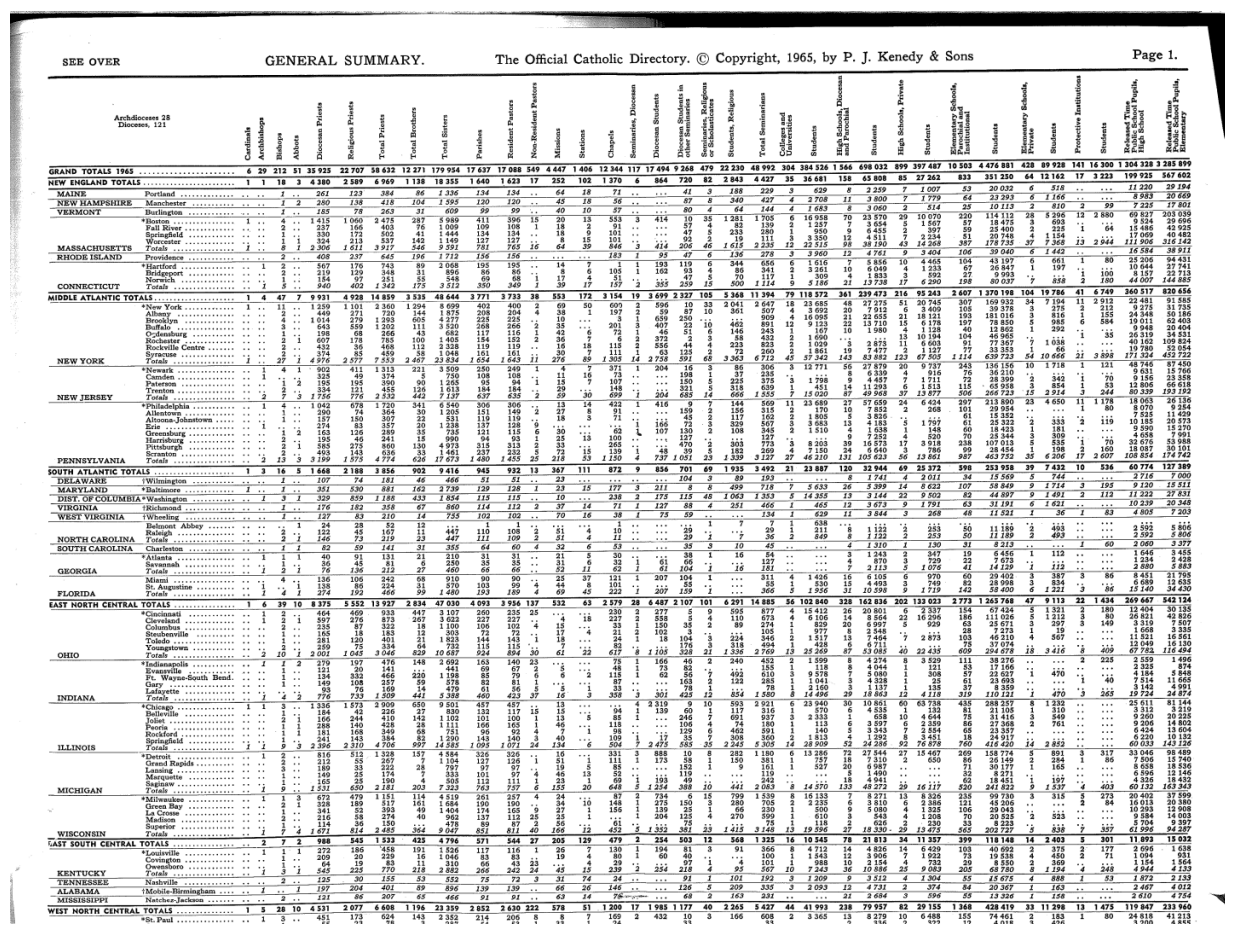

